\title{
Water and radiation use efficiencies of irrigated biomass sorghum in a Mediterranean environment
}

\author{
Pasquale Garofalo, Alessandro Vittorio Vonella, Sergio Ruggieri, Michele Rinaldi \\ CRA-Unità di Ricerca per lo studio dei Sistemi Colturali degli Ambienti caldo-aridi, Bari, Italy
}

\begin{abstract}
Biomass sorghum (Sorghum bicolor L. Moench) is a crop that can be used for energy production in the bioethanol chain and a greater knowledge of its potential and response to irrigation water levels could help to assess its potential diffusion in Mediterranean areas. A twoyear field experiment was carried out in Southern Italy; two irrigation regimes were compared in biomass sorghum, optimal watered (irrigation supplies greater than actual crop evapotranspiration, ETc) and stressed watered (about $65 \%$ of the optimal one). Growth analysis, soil water content and aboveground dry biomass $(A D M)$ yield at harvest were measured and analyzed. Radiation use efficiency (RUE), irrigation (IWUE) and water use efficiencies (WUE) were also calculated. Seasonal water use ranged from $830 \mathrm{~mm}$ in the optimal treatment to $589 \mathrm{~mm}$ in the stressed one. Similarly, $A D M$ proved to be statistically different between the two irrigation treatments (34.6 vs $19.8 \mathrm{t}$ of dry matter ha-1). The RUE, calculated as the slope of the first order equation between dry biomass and intercepted photosynthetically active radiation along a crop cycle, showed an average of $2.84 \pm 0.65 \mathrm{~g} \mathrm{MJ}^{-1}$. No statistical differences for IWUE and $W U E$ were obtained between irrigation regimes ( 8.22 and $5.87 \mathrm{~kg} \mathrm{~m}^{-3}$, on average). The two years of experiment influenced IWUE and WUE (both larger in the rainier growing season), but not the RUE. The high RUE and WUE obtained values confirmed that biomass sorghum is a crop with considerable dry matter production efficiency. The experimental results suggest that the introduction of biomass sorghum in the cropping systems of
\end{abstract}

Correspondence: Michele Rinaldi, CRA-Unità di Ricerca per lo studio dei Sistemi Colturali degli Ambienti caldo-aridi, via Celso Ulpiani 5, 70125 Bari, Italy.

Tel. +39.080 .5475016 - Fax: +39.080 .5475023 .

E-mail: michele.rinaldi@entecra.it

Key words: Sorghum bicolor L. Moench., plant biomass, irrigation water use efficiency, water use, energy crop.

Acknowledgments: this work has been supported by Italian Ministry of Agriculture and Forestry Policies under contract n. 209/7393/05 (AQUATER Project).

Received for publication: 18 October 2011.

Accepted for publication: 8 April 2011.

(C) Copyright P. Garofalo et al., 2011

Licensee PAGEPress, Italy

Italian Journal of Agronomy 2011; 6:e21

doi:10.4081/ija.2011.e21

This work is licensed under a Creative Commons Attribution NonCommercial 3.0 License (CC BY-NC 3.0).
Mediterranean environments as an alternative crop for energy purposes is feasible, but requires an adequate seasonal irrigation water supply (not less than $500 \mathrm{~mm}$ ).

\section{Introduction}

Biomass from vegetation is one of the principal sources for energy purposes, providing the $14 \%$ of world-wide energy needs (IEA, 1998) and has an important economic role (Parikka, 2004). Moreover, this energy source is renewable, usable as production of biofuels or combustible dry matter, with low $\mathrm{CO}_{2}$ emission and low costs (Berndes et al., 2003; Antonopoulou et al., 2008). Currently, for energy purpose, sweet sorghum (Sorghum bicolor L. Moench) is considered an important crop, in biofuel production, encouraged by the European Community directives, thanks to the possibility to cultivate this crop in set-aside lands, and so with an economic enhance in South-European regions. Sweet sorghum, as reported by some authors (Mastrorilli et al., 1995), shows a high potential in term of adaptability to pedo-climatic condition for this Mediterranean environment. For energy purpose it is important that the resources needed to the growth, mainly water and solar radiation, are fully exploited to obtain high amount of biomass per unit of resource utilized by the crop.

Radiation use efficiency (RUE) and water use efficiency (WUE) are crop parameters that contain the plant behaviour, in response to different factors, linked not only to intercepted radiation, but also to the water stress, photosynthetic conditions and so on.

Some authors report $R U E$ as a stable parameter for many crops (Hughes et al., 1987; Monteith, 1989), but variability in RUE was also pointed out by other authors (Sinclair and Muchow, 1999). However, it is important to take into account variations in $R U E$ particularly because it can change with water supply. For instance, values of $R U E$ in sweet sorghum ranging from between 3.4 to $4.7 \mathrm{~g}$ of aboveground dry matter $\mathrm{MJ}^{-1}$ of intercepted PAR were found by Mastrorilli $e$ t al. (1995) and Perniola et al. (1996) in well-watered crop conditions in a Mediterranean environment. A RUE value of $3.6 \mathrm{~g} \mathrm{MJ}^{-1}$ was found by Varlet-Grancher et al. (1992) in Northern Europe (France). Dercas and Liakantas (2007) confirmed that $R U E$ is closely related to crop water status, with values of $3.55 \mathrm{~g} \mathrm{MJ}^{-1}$ for non-water stressed crops and 1.30 $\mathrm{g} \mathrm{MJ}^{-1}$ for stressed crops. For grain sorghum, the value of $R U E$ is lower than sweet sorghum, as reported by Albrizio and Steduto (2005), with a value equal to $2.6 \mathrm{~g} \mathrm{MJ}^{-1}$.

For $W U E$ as well, differences are noticeable between sweet and grain sorghum, with an advantage for sweet sorghum (6.0-4.1 $\mathrm{kg} \mathrm{m}^{-3}$ Mastrorilli et al., 1995; 8.6-6.5 $\mathrm{kg} \mathrm{m}^{-3}$ Saeed and El-Nadi, 1988), greater if compared with grain sorghum $\left(4.4-5.5 \mathrm{~kg} \mathrm{~m}^{-3}\right.$ in Steduto and Albrizio, 2005). Grain sorghum is less suitable for energy production, because it is shorter (1-2 m) than sweet sorghum (up to $3 \mathrm{~m}$ ) and has a less vigorous stem. Besides, from the RUE and WUE reported by above cited authors, it is clear as sweet sorghum has a better capacity 
than grain sorghum to convert the solar radiation and water into biomass and this latter converted in bioethanol (Billa et al., 1997; Ratnavathi et al., 2010). Recently, new cultivars of sorghum have been commercialized, so called biomass sorghum, with morphological characteristics that make suitable for great biomass production to energy purpose; remarkable height (up to $3.5 \mathrm{~m}$ ), elevated sucker growth and a large amount of cellulose and water in the internodes marrows accumulated during growth stages, are morphological traits important to convert fresh biomass into biofuel. No bibliographic references were found for biomass sorghum grown under Mediterranean conditions; consequently, each comparison between our data and that of other authors can be done only for sweet or grain sorghum.

The RUE and WUE variability casts doubt on the use of a fixed value for these parameters in sorghum in different climatic and environmental conditions, as applied in many crop growth simulation models, both solar-driven (DSSAT, Jones et al., 2003; EPIC, Sharpley and Williams, 1990) and water-driven (CropSyst, Stockle et al., 2003; AQUACROP, Steduto et al., 2009). For these reasons it is important to evaluate the response of biomass sorghum productivity to different irrigation strategies in new pedo-climatic conditions through the determination of the $R U E$ and $W U E$ parameters. The aims of this study were to estimate $R U E$ and $W U E$ parameters and determine the yield potentiality of biomass sorghum when managed with different water regimes in a Mediterranean environment.

\section{Materials and Methods}

\section{Experimental site}

The field experiment was carried out in 2008 and 2009 in Foggia (lat. $41^{\circ} 8^{\prime} 7^{\prime \prime} \mathrm{N}$; long. $15^{\circ} 83^{\prime}$ 5” E, alt. $90 \mathrm{~m}$ a.s.l.), southern Italy.

The soil is a vertisol of alluvial origin, Typic Calcixeret, (Soil Taxonomy $10^{\text {th }}$ ed., USDA 2006), and is silty-clay with the following characteristics: organic matter, 2.1\%; total $\mathrm{N}, 0.122 \%$; $\mathrm{NaHCO}_{3}$ extractable $\mathrm{P}, 41 \mathrm{ppm} ; \mathrm{NH}_{4} \mathrm{O}$ Ac-extractable $\mathrm{K}_{2} \mathrm{O}, 1598 \mathrm{ppm}$; $\mathrm{pH}$ (water), 8.3 ; field capacity water content, $0.396 \mathrm{~m}^{3} \mathrm{~m}^{-3}$; permanent wilting point water content, $0.195 \mathrm{~m}^{3} \mathrm{~m}^{-3}$, available soil water, $202 \mathrm{~mm} \mathrm{~m}^{-1}$. The climate is accentuated thermo-Mediterranean (Unesco-FAO classification), with temperatures below $0^{\circ} \mathrm{C}$ in the winter and above $40^{\circ} \mathrm{C}$ in the summer. Annual rainfall (average $550 \mathrm{~mm}$ ) is mostly concentrated during the winter months and class $A$ pan evaporation exceeds $10 \mathrm{~mm}$ day $^{-1}$ in summer. Daily meteorological data (temperatures, humidity, rainfall, wind velocity and solar radiation) were recorded by the local meteorological station.

\section{Field experiment}

Biomass sorghum (cv BIOMASS 133) was sown on $9^{\text {th }}$ and $12^{\text {th }}$ May in the first and second years respectively, in rows $0.5 \mathrm{~m}$ apart and a distance of $0.08 \mathrm{~m}$ between seeds in each row $(250,000$ seeds per hectare). The crop was harvested before heading on $12^{\text {th }}$ and $20^{\text {th }}$ August in 2008 and 2009, respectively. Biomass sorghum is indicated for biofuel production and this requires harvesting the plant at the right water content; in fact, for the fermentative processes, necessary to obtain ethanol, it is essential that the glucosides in the plant biomass are simply, and the substratum is rich of water (70-75\%). A delayed harvest has as consequence the synthesis of more complex glucosides as cellulose and lignin and less efficient industrial processes to obtain ethanol. Moreover, the net gain in term of biomass by grain production is negligible; so the heading it seems to be the right time for crop harvest. In the first year, the crop evapotranspiration $\left(E T_{c}\right.$, in $\left.\mathrm{mm}\right)$ was measured by means of two weighted lysimeters (area of $4 \mathrm{~m}^{2}$ and a depth of 1.5 $\mathrm{m})$, located in the middle of a $100 \times 100 \mathrm{~m}$ field, to reduce the fetch influence. Daily weight data were collected and no drainage water was observed at the bottom of the lysimeters. Runoff was considered equal to zero because of the flat-lying nature of the land. Daily crop measured evapotranspiration $\left(E T_{c}\right.$, in $\left.\mathrm{mm}\right)$ was calculated as:

$$
E T_{c}=\frac{\left(W L_{i}-W L_{i-1}\right)}{4}-I-R_{i-1}
$$

where $W L_{i}$ and $W L_{i-1}$ are the lysimeter weights in $\mathrm{kg}$ at day $i$ and $i-1$ respectively, $I$ is the irrigation amount in $\mathrm{mm}$ and $R$ is the rain in $\mathrm{mm}$. The average values of two lysimeters were used.

During the field experiment, climate data were measured by a standard meteorological station, located on a grassy area near the experimental field. Maximum and minimum temperatures, global solar radiation, precipitation, wind speed and relative maximum and minimum air humidity were collected on a daily basis. The irrigation schedule was set as a function of $E T_{c}$ : each time $E T_{c}$ reached $60 \mathrm{~mm}$, irrigation started according to the percentage of $E T_{c}$ recovery; optimal treatment, with more than $100 \%$ of $E T_{c}$ and stressed treatment with more than $60 \%$. The reference evapotranspiration $\left(E T_{0}\right.$, in $\left.\mathrm{mm}\right)$ was calculated using the FAO-Penman-Monteith method (Allen et al., 1998). The crop coefficient $\left(K_{c}\right)$ was calculated as the ratio between $E T_{c}$ and $E T_{0}$, for initial, development and middle crop stages.

In the second year (2009), the irrigation regime schedule was based on crop evapotranspiration $\left(E T_{c}\right)$ estimated as follows, using the $K_{c}$ values derived from the first year of the experiment:

$$
E T_{c}=E T_{0} * K c
$$

Each time the cumulated $E T_{c}$ reached $60 \mathrm{~mm}$ (subtracting rainfall), irrigation started in the same way as in the four irrigation treatments described above for the first year. To ensure uniform water distribution, a drip irrigation system was used, with one line for each plant row and drippers with a $4 \mathrm{~L} \mathrm{~h}^{-1}$ flow. A water flow meter was placed at the head of each plot to measure the amount of irrigation water supplied accurately. A pre-sowing fertilization was applied with $72 \mathrm{~kg} \mathrm{ha}^{-1}$ of $\mathrm{N}$ and $87 \mathrm{~kg} \mathrm{ha}^{-1} \mathrm{P}_{2} \mathrm{O}_{5}$ as diammonium phosphate. The experimental treatments were arranged in a completely randomized block design, with four replications and elementary plots of $80 \mathrm{~m}^{2}$. Gravimetric soil water measurements were carried out at depths of $0.2,0.4,0.6$ and $0.8 \mathrm{~m}$ at sowing, harvest and growth analysis sampling dates.

Growth analysis was carried out from June to August; at five sampling dates, aboveground plant dry matter $(A D M)$, separated into stems, green and dead leaves, was measured by taking a 0.5 linear meter sample from each plot which was then dried at $80^{\circ} \mathrm{C}$ until the weight was constant. The last sampling was in correspondence with the plant harvest. Leaf Area Index ( $L A I)$ - the destructive method - was determined measuring green leaf area with Delta T Devices (Decagon Devices Inc., Pullman, WA, USA). Seasonal water use $(W U)$ was estimated in both years according to the following simplified water balance equation:

$$
W U=\Delta S W C+R+I
$$

where $\triangle S W C$ is the variation, between seeding and harvest dates, of the volumetric soil water content in the $0-0.8 \mathrm{~m}$ depth layer, $R$ is rainfall and $I$ irrigation, all expressed in $\mathrm{mm}$; runoff and capillary rise were considered negligible. 


\section{Crop parameter derivation}

Water use efficiency and Irrigation water use efficiency (WUE; IWUE, $\mathrm{kg} \mathrm{m}^{-3}$ ) were calculated as the slope of the first order equation between $A D M$ and $W U$ (both measured at each sampling date) and seasonal irrigation amount, respectively. For regression between irrigation supplies and $A D M$, the intercept was forced to zero, whereas in the regression between $A D M$ and $W U$, the values of intercept gave an indication of water lost by soil evaporation (Passioura, 1977).

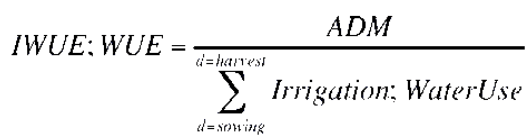

The photosynthetic active radiation (PAR) was estimated using the following equation:

$$
P A R=R g * 0.48
$$

Global solar radiation $(R g)$ was measured with a thermophile pyranometer (305-2800 $\mathrm{nm}$ wave-length range).

The intercepted PAR (IPAR) was estimated with the formula:

$$
i P A R=P A R^{*} I E
$$

where $I E$ is the interception efficiency for the canopy crop, calculated with Beer's law, as:

$$
I E=1-e^{\left(-\mathrm{k}^{*} L A I_{d}^{*} C f\right)}
$$

where $k$ is the light extinction coefficient, calculated as the slope of fit ted regression between the natural logarithm of diffuse non-intercepted sky radiation and $L A I$, both measured with an $\mathrm{LI}-\mathrm{COR} 2000$ portable area meter in 2008. For each plot the data were taken from an average of 6 measurements carried out below the plant canopy during a daytime period between 12:00pm and 2:00pm at each growing sample.

$L A I_{d}$ is the green leaf area and $C f$ is the clumping factor (Nilson, 1971; Lang, 1986, 1987), calculated with the following equation, where $L A I_{d}$ is the green leaf area index measured with the destructive method (Delta T Device equipment) as:

$$
C f=0.75+(0.25) *\left(1-e^{\left(-0.35^{*} L A I_{d}\right)}\right)
$$

Radiation use efficiency ( $R U E, \mathrm{~g} \mathrm{MJ}^{-1}$ of $\left.i P A R\right)$ was calculated as the slope of the first order equation between aboveground dry matter in the biomass $(A D M)$ and cumulated intercepted photosynthetic active radiation (iPAR) at each sampling date. The values of Y-axis intercepts proved not to be different from zero; moreover, the test confirmed that intercepts were equal to zero and thus the regression lines were forced to pass from the axis origin (Charles-Edwards, 1982).

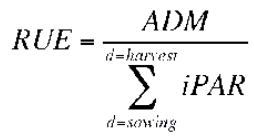

Analysis of variance was carried out considering year as a random effect and irrigation as a fixed effect, arranged in a randomized block design model; the Least Significant Difference was used to compare mean values.

\section{Results and Discussion}

\section{Climatic behaviour}

The maximum $\left(T_{\max }\right)$ and minimum temperatures $\left(T_{\min }\right)$ (Table 1) were similar over the two years, except for May, where 2009 was characterized by $T_{\max }$ and $T_{\min }$ greater than those of 2008 . In the first part of the crop growing cycle (20 days after sowing), $T_{\max }$ showed daily values until $8^{\circ} \mathrm{C}$ greater when compared with long-term averages. The same consideration can be made for daily global radiation, with high values in May 2009, which were not, however, fundamental on crop growth (sowing dates: $9^{\text {th }}$ and $12^{\text {th }}$ May; emergence dates: $20^{\text {th }}$ and $25^{\text {th }}$ May, in 2008 and 2009 , respectively). In the first year, accumulated rainfall during the crop cycle was greater by about $10 \mathrm{~mm}$ when compared with 2009 , but from $1^{\text {st }}$ January to the sowing date, accumulated rainfall in the second year was $418 \mathrm{~mm}$. By contrast, in the same period in the first year only $168 \mathrm{~mm}$ was recorded. This large difference in rainfall resulted in greater water availability for the second rather than in the first year of the experiment, as well as in deeper soil layers. Comparable averages were observed in both years as regards daily reference evapotranspiration $\left(E T_{0}\right)$, but these were slightly lower than long-term values.

\section{Irrigation and water use}

In the first year, the greatest component of $W U$ (eq. 3) was the irrigation water $(I)$, while in the second year the soil moisture variation from sowing to harvest $(\triangle S W C$ ) (Table 2). Indeed, as regards the soil

Table 1. Meteorological data (monthly averages) recorded in Foggia (Italy) in 2008, 2009 and long-term period (1952-2007).

\begin{tabular}{lccccc} 
& Year & May & June & July & August \\
Daily $\mathrm{T}_{\text {max }}\left({ }^{\circ} \mathrm{C}\right)$ & 2008 & 25.2 & 30.1 & 32.6 & 34.0 \\
& 2009 & 27.2 & 29.0 & 32.7 & 33.7 \\
& $1952-2007$ & 25.0 & 29.4 & 31.9 & 31.3 \\
Daily $_{\min }\left({ }^{\circ} \mathrm{C}\right)$ & 2008 & 10.8 & 15.8 & 18.8 & 19.5 \\
& 2009 & 12.6 & 15.6 & 18.8 & 19.6 \\
& $1952-2007$ & 11.5 & 15.6 & 18.5 & 18.8 \\
\hline $\mathrm{R}_{\mathrm{g}}\left(\mathrm{MJ} \mathrm{m}^{-2}\right.$ month $\left.^{-1}\right)$ & 2008 & 750 & 757 & 851 & 789 \\
& 2009 & 847 & 770 & 883 & 773 \\
${\text { Rain }\left(\mathrm{mm} \mathrm{month}^{-1}\right)}^{1952-2007}$ & 744 & 813 & 836 & 715 \\
& 2008 & 30.2 & 41.0 & 3.8 & 0.4 \\
& 2009 & 19.4 & 25.8 & 13.2 & 1.4 \\
ET $_{0}\left(\mathrm{~mm} \mathrm{~d}^{-1}\right)$ & $1952-2007$ & 33.7 & 33.5 & 20.4 & 32.6 \\
& 2008 & 4.4 & 5.2 & 6.0 & 5.6 \\
& 2009 & 4.9 & 5.1 & 6.0 & 5.4 \\
& $1952-2007$ & 4.9 & 5.7 & 6.0 & 5.8 \\
\hline
\end{tabular}

Table 2. Main parameters of irrigation in biomass sorghum during the two experimental years. $\triangle \mathrm{WSC}=$ soil water depletion from sowing to harvest in the $0-1 \mathrm{~m}$ soil depth.

\begin{tabular}{lccccc}
\hline Year & $\begin{array}{c}\text { Irrigation } \\
\text { regimes }\end{array}$ & $\begin{array}{c}\mathbf{N}^{\circ} \text { of } \\
\text { irrigation }\end{array}$ & $\begin{array}{c}\text { Irrigation } \\
\text { water applied } \\
\text { mm }\end{array}$ & $\begin{array}{c}\text { Water } \\
\text { used } \\
\text { mm }\end{array}$ & $\begin{array}{c}\Delta W S C \\
\text { mm }\end{array}$ \\
\multirow{2}{*}{2008} & Optimal & 8 & 505 & 712 & 143 \\
& Stressed & 8 & 325 & 589 & 200 \\
& Avg & 8 & 415 & 650 & 171 \\
& Optimal & 6 & 335 & 830 & 403 \\
& Stressed & 6 & 215 & 648 & 341 \\
& Avg & 6 & 275 & 739 & 372 \\
\hline \multirow{2}{*}{$2008-09$ Av. } & Optimal & 7 & 420 & 771 & 273 \\
& Stressed & 7 & 270 & 619 & 271 \\
& Avg & 7 & 345 & 695 & 272 \\
\hline
\end{tabular}


water content at sowing (0-0.8 m soil depth), more was available in the second than in the first year (about $100 \mathrm{~mm}$ ). This could explain the greater amount of water supplied by irrigation in the first year of experiment when compared with the second year; in 2008 irrigation was 415 $\mathrm{mm}$, while in 2009 the water supplied with irrigation was $275 \mathrm{~mm}$, on average over the two water regimes. The difference between the two years was as large as the applied irrigation water was small. In 2008 the water used by the sorghum ranged from 712 to $589 \mathrm{~mm}$; in 2009, from 830 to $648 \mathrm{~mm}$, in the optimal and stressed treatments, respectively. This difference can be attributed to the capability of sorghum to extract water from the deeper layers of the soil: in 2009 these were almost certainly wetter than in 2008 as a result of large rainfall before the sowing date. The stressed irrigation regime allowed for a saving of a couple of irrigation supplies and a saving of $35 \%$ of irrigation water in both years but only a reduction of $20 \%$ for seasonal $W U$ with respect to the optimal regime.

\section{Crop coefficients}

In 2008, during the first part of crop cycle, from the beginning to $50 \%$ of canopy expansion, the $E T_{c}$ oscillated among 1.1 and $2.2 \mathrm{~mm} \mathrm{~d}^{-1}$. At maximum canopy expansion (about 60 days after sowing), ETc reached the maximum values ranging between 8.3 and $10.3 \mathrm{~mm} \mathrm{~d}^{-1}$. Seasonal $E T_{0}$ was $507 \mathrm{~mm}$, whereas $E T_{c}$ was $570 \mathrm{~mm}$.

The ratio between the evapotranspiration measured by weighted lysimeter and the reference evapotranspiration allowed us to calculate the crop coefficients (Allen et al., 1998) specific for biomass sorghum; the length for the initial, development and middle stage, was equal to 25,25 and 46 days, respectively, with values of $K c$ equal to 0.51 for the initial and 1.49 for the middle stage. This latter calculated $K c$ was higher than those suggested by FA0, even if the FAO values are referred to sweet (1.20) and grain sorghum (1.10) and not for biomass sorghum.

\section{Biomass yield}

Table 3 shows the sorghum biomass yield at harvest, separated into stems and leaves and total $\left(A D M ; \mathrm{g} \mathrm{m}^{-2}\right)$ recorded in both years and averaged over irrigation treatments. During crop growing cycles in the first year, no statistical differences were found, while at harvest the optimal produced $A D M$ of about $35 \%$ greater than stressed; this is mainly explained by stem yield.

Leaf Area Index (Figure 1) in the first year was similar for both water treatments, reaching its maximum value after $844 \mathrm{GDD}$ with 7.7 and $6.5 \mathrm{~m}^{2} \mathrm{~m}^{-2}$ for optimal and stressed treatments, respectively. Only at harvest the LAI was higher in optimal than in stressed. In the second year, the maximum $L A I$ was reached at $1042 \mathrm{GDD}$ for the optimal treatment with a value equal to $8.2 \mathrm{~m}^{2} \mathrm{~m}^{-2}$, whereas for the stressed treatment the maximum $L A I$ was $5.7 \mathrm{~m}^{2} \mathrm{~m}^{-2}$, reached earlier (988 GDD). $L A I$ development was different for the greater part of the crop growth cycle, even if at harvest the $L A I$ was similar in both treatments.

The $A D M$ was similar in the two years of experiment; in 2008 the differences between irrigation regimes occurred only at harvest, while in 2009 after the first irrigation, the treatments influenced sorghum yield and at harvest the $A D M$ produced by the optimal irrigation regimes were $45 \%$ greater than the stressed ones, with a proportional prevalence of leaf respect to weight stems (Figure 2).

The potential of this crop is high, considering its short growth period (80-100 days): the dry biomass yield level (from 2000 to $3700 \mathrm{~g} \mathrm{~m}^{-2}$, equivalent to $20-37 \mathrm{t}$ of dry matter ha $\mathrm{h}^{-1}$ ) is in accordance with results obtained in similar environments and with similar water availability. For example, for sweet sorghum $A D M$ varied from 3100 to $1700 \mathrm{~g} \mathrm{~m}^{-2}$ in Greece (Dercas and Liakatas, 2007) with $680 \mathrm{~mm}$ and $450 \mathrm{~mm}$ of seasonal $E T_{c}$ respectively, and from 3250 to $3170 \mathrm{~g} \mathrm{~m}^{-2}$ in a similar environment, with a seasonal $E T_{c}$ equal to 580 and $526 \mathrm{~mm}$. For grain sorghum, Farah et al., (1997) found values of $A D M$ in Sudan oscillating between $3050 \mathrm{~g} \mathrm{~m}^{-2}$ and $2210 \mathrm{~g} \mathrm{~m}^{-2}$, passing from 627 to $498 \mathrm{~mm}$ of water supplied; the lowest $A D M$ was obtained by Farrè and Faci (2006) in Northern Spain, with values of $1838 \mathrm{~g} \mathrm{~m}^{-2}$ for $588 \mathrm{~mm}$ of evapotranspiration and $522 \mathrm{~g} \mathrm{~m}^{-2}$ for $274 \mathrm{~mm}$ of water used by sorghum. Habyarimana et al. (2004) reported how ADM in biomass sorghum can oscillate between 2900 and $2000 \mathrm{~g} \mathrm{~m}^{-2}$ in rainfed conditions and from 5100 to $3500 \mathrm{~g} \mathrm{~m}^{-2}$ in well-watered conditions.

\section{Radiation use efficiency}

The estimation of intercepted PAR, and so of RUE, was done on $L A I_{d}$ measured experimentally for all treatments and for all years, using $k$ (extinction coefficient) value derived from 2008 ; the $k$ value $(-0.57)$ obtained in this experiment is slightly higher than those reported by Curt et al. (1998) in central Spain $(k=-0.62)$, by Perniola et al. (1996)

Table 3. Biomass sorghum productive traits: average values of the two years and, for each year among irrigation treatments, followed by different letters, are different at $\mathbf{P}=\mathbf{0 . 0 5}$ (LSD test).

\begin{tabular}{|lllcc} 
Year & $\begin{array}{l}\text { Irrigation } \\
\text { regimes }\end{array}$ & $\begin{array}{c}\text { Total } \\
\text { aboveground } \\
\text { plant dry } \\
\text { matter } \\
\left(\mathrm{g} \mathrm{m}^{-2}\right)\end{array}$ & $\begin{array}{c}\text { Stems } \\
\left(\mathrm{g} \mathrm{m}^{-2}\right)\end{array}$ & $\begin{array}{c}\text { Leaves } \\
\left(\mathrm{g} \mathrm{m}^{-2}\right)\end{array}$ \\
\hline \multirow{2}{*}{2008} & Optimal & $3000 \mathrm{a}$ & $2365 \mathrm{a}$ & $650 \mathrm{a}$ \\
& Stressed & $1908 \mathrm{~b}$ & $142 \mathrm{~b}$ & $483 \mathrm{~b}$ \\
& Avg & $2454 \mathrm{a}$ & $1895 \mathrm{~b}$ & $567 \mathrm{~b}$ \\
& Optimal & 3762 & $2591 \mathrm{a}$ & $1171 \mathrm{a}$ \\
& Stressed & 2018 & $1445 \mathrm{~b}$ & $573 \mathrm{~b}$ \\
& Avg & $2890 \mathrm{a}$ & $2018 \mathrm{a}$ & $872 \mathrm{a}$ \\
\hline & Optimal & $3460 \mathrm{a}$ & $2490 \mathrm{a}$ & $960 \mathrm{a}$ \\
& Stressed & $1980 \mathrm{~b}$ & $1440 \mathrm{~b}$ & $540 \mathrm{~b}$ \\
& Avg & 2720 & 1965 & 750 \\
\hline
\end{tabular}

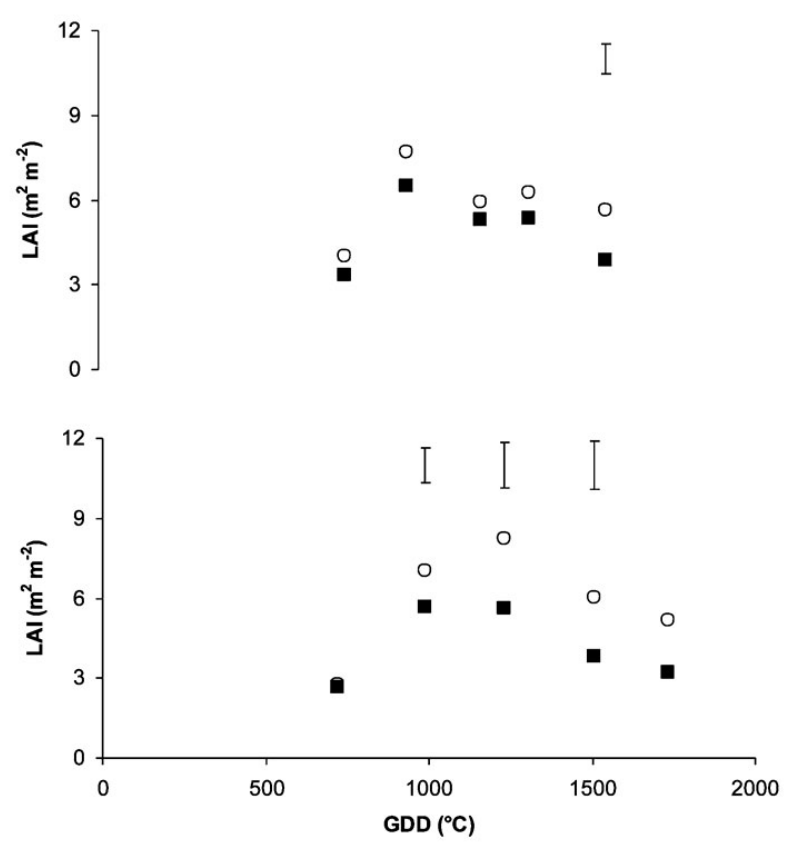

Figure 1. Green Leaf Area index ( $L A I)$, recorded for biomass sorghum during the two seasonal experiments (2008 above, 2009 under). For treatments: optimal = empty circle; stressed $=$ full square. Vertical bars indicate differences statistically significant for each sampling (LSD test; $P=0.05$ ). 
( $k=-0.60)$ in southern Italy and 0.65 by Dercas and Liakatas (2007) in central Greece.

The value for clumping factor $\left(C_{f}\right)$ is closely dependent from $L A I_{d}$ and for this reason oscillation in the value was due to the different growth stage and water regimes, varying between 0.75 and 0.99 among years and irrigations treatments.

The analysis of variance of $R U E$ values showed no significant effects for year $x$ irrigation interaction, but highly significant effects for the irrigation source of variation, either by individual year or pooling together the two years of experiment.

Average $R U E$ values were $2.75 \pm 0.21 \mathrm{~g} \mathrm{MJ}^{-1}$ in 2008 and $2.92 \pm 0.80 \mathrm{~g}$ $\mathrm{MJ}^{-1}$ in 2009 (Table 4). In both years the highest value of $R U E$ was reached in the optimal irrigated treatment, the lowest value in the stressed one. In general, the overall average of $2.84 \pm 0.65 \mathrm{~g} \mathrm{MJ}^{-1}$ is in agreement with the values reported by Monteith (1977) as an average for $\mathrm{C}_{4}$ crops. The RUEs calculated in our experiment ranged from a minimum of 2.29 to a maximum of $3.56 \mathrm{~g} \mathrm{MJ}^{-1}$ and include the values obtained by the authors cited above.

In previous research studies the influence of crop water use on $R U E$ was also observed: Perniola et al. (1995) reported $4.7 \mathrm{~g} \mathrm{MJ}^{-1}$ with a water consumption of $870 \mathrm{~mm}$, Mastrorilli et al. (1995) reported $3.4 \mathrm{~g}$ $\mathrm{MJ}^{-1}$ in a similar environment and with a crop water use of $550 \mathrm{~mm}$, while a value of $3.6 \mathrm{~g} \mathrm{MJ}^{-1}$ was found by Varlet-Grancher et al. (1992) in France; Dercas and Liakatas (2007) calculated values of RUE between $3.55 \mathrm{~g} \mathrm{MJ}^{-1}$ for non-water stressed crops and $1.30 \mathrm{~g} \mathrm{MJ}^{-1}$ in stressed crops in relation to $657 \mathrm{~mm}$ and $421 \mathrm{~mm}$ of plant water used, respectively. This confirms that $R U E$ is significantly dependent on crop water consumption and that it cannot be considered a stable crop parameter, at least in the case of biomass sorghum.

Singh and Singh (1995) reported how sorghum reduces stomatal conductance by about $18 \%$ and $L A I$ by $20 \%$ when water availability is at $60 \%$ of optimal soil moisture conditions. These authors also reported a reduction in net photosynthesis for sorghum that follows the reduction in stomatal conductance. Studies on sunflowers (Takami et al., 1982) confirmed that one of the effects of soil water reduction on plant development is the reduction of leaf area expansion as a result of a decline in the expansion rate but not of the duration of expansion. LAI values, recorded during crop growth, were statistically different among the water regimes in both years in most sampling (Figure 1). Even if $L A I$ was different, $I P A R$ did not differ between the irrigation regimes and this means that maximum $i P A R$ is already intercepted at $L A I=3$. By contrast, $R U E$ was significantly different between irrigation regimes (Figure 3), with values of $3.31 \pm 0.44 \mathrm{~g} \mathrm{MJ}^{-1}$ for optimal and $2.30 \pm 0.41$ $\mathrm{g} \mathrm{MJ}^{-1}$ for stressed sorghum. Probably, at the same level of intercepted

Table 4. Biomass sorghum radiation use efficiency, water and irrigation use efficiencies: average values of the two years and, for each year among irrigation treatments, followed by different letters, are different at $\mathbf{P}=\mathbf{0 . 0 5}$ (LSD test).

\begin{tabular}{|c|c|c|c|c|}
\hline Year & $\begin{array}{l}\text { Irrigation } \\
\text { regimes }\end{array}$ & $\begin{array}{c}\text { Radiation } \\
\text { use } \\
\text { efficiency } \\
(\mathrm{g} \mathrm{MJ}-1)\end{array}$ & $\begin{array}{l}\text { Irrigation } \\
\text { water } \\
\text { use } \\
\text { efficiency } \\
\left(\mathrm{kg} \mathrm{m}^{-3}\right)\end{array}$ & $\begin{array}{l}\text { Water } \\
\text { use } \\
\text { efficiency } \\
\left(\mathrm{kg} \mathrm{m}^{-3}\right)\end{array}$ \\
\hline 2008 & $\begin{array}{c}\text { Optimal } \\
\text { Stressed } \\
\text { Avg }\end{array}$ & $\begin{array}{c}2.99 \mathrm{a} \\
2.51 \mathrm{~b} \\
2.75\end{array}$ & $\begin{array}{l}4.60 \mathrm{~b} \\
5.39 \mathrm{a} \\
4.99 \mathrm{a}\end{array}$ & $\begin{array}{l}4.84 \mathrm{a} \\
4.38 \mathrm{a} \\
4.44 \mathrm{~b}\end{array}$ \\
\hline 2009 & $\begin{array}{c}\text { Optimal } \\
\text { Stressed } \\
\text { Avg }\end{array}$ & $\begin{array}{c}3.56 \mathrm{a} \\
2.29 \mathrm{~b} \\
2.92\end{array}$ & $\begin{array}{l}11.35 \mathrm{a} \\
11.53 \mathrm{a} \\
11.44 \mathrm{~b}\end{array}$ & $\begin{array}{l}8.20 \mathrm{a} \\
6.27 \mathrm{a} \\
7.24 \mathrm{a}\end{array}$ \\
\hline $2008-09 \mathrm{Av}$. & $\begin{array}{c}\text { Optimal } \\
\text { Stressed } \\
\text { Avg }\end{array}$ & $\begin{array}{c}3.23 \mathrm{a} \\
2.37 \mathrm{~b} \\
2.84\end{array}$ & $\begin{array}{c}7.98 \mathrm{a} \\
8.46 \mathrm{a} \\
8.22\end{array}$ & $\begin{array}{c}6.78 \mathrm{a} \\
5.49 \mathrm{a} \\
5.87\end{array}$ \\
\hline
\end{tabular}

radiation, plants with a different water status have a different stomata process regulation and thus different net photosynthesis levels. These considerations were supported by Krampitz et al. (1984), who underlined that both the gross and net photosynthesis in sunflowers declined linearly to low to moderate water stress. Other effects of water stress reported in literature are a reduction in intercellular $\mathrm{CO}_{2}$ concentration with a consequent reduction in the net photosynthesis observed in sorghum (Kreig and Hutmacher, 1986), an increase of stomata resistance in cotton and millet (Troughton, 1969; Ludlow and Ng, 1976) and stomatal closure caused by the abscisic acid produced by plants (Davies et al., 1994; Davies and Gowing, 1999). All these effects of water availability can sufficiently explain the $R U E$ level and its variations.

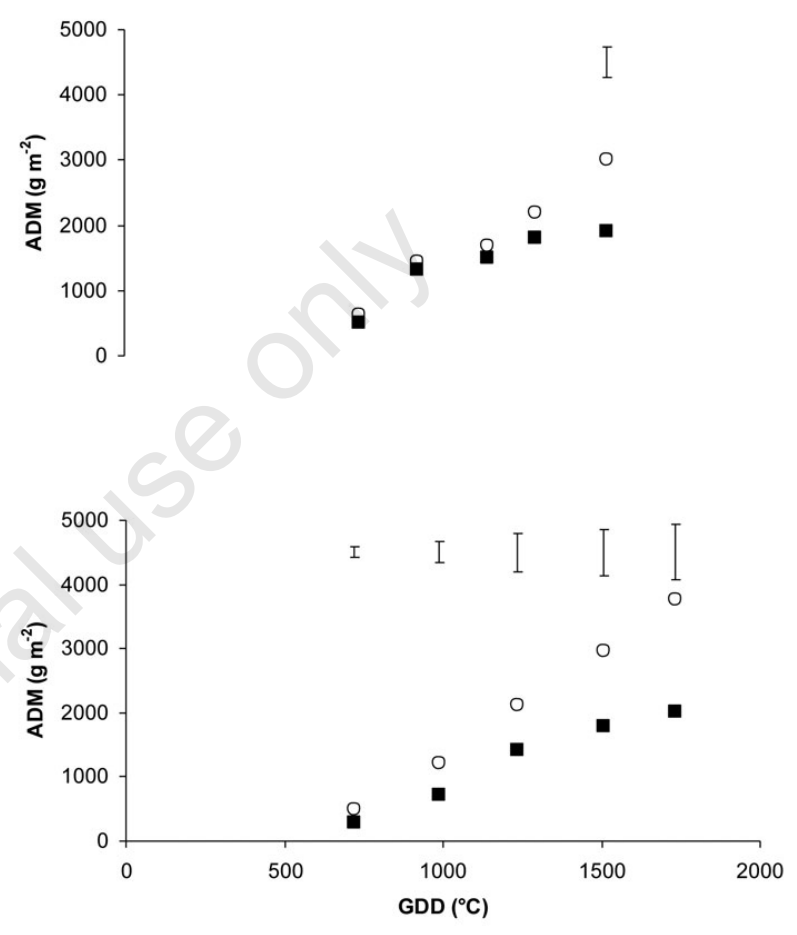

Figure 2. Aboveground plant dry matter recorded for biomass sorghum during the two seasonal experiments (2008 above, 2009 under). For treatments: optimal = empty circle; stressed $=$ full square. Vertical bars indicate differences statistically significant for each sampling (LSD test; $\mathbf{P}=\mathbf{0 . 0 5}$ ).

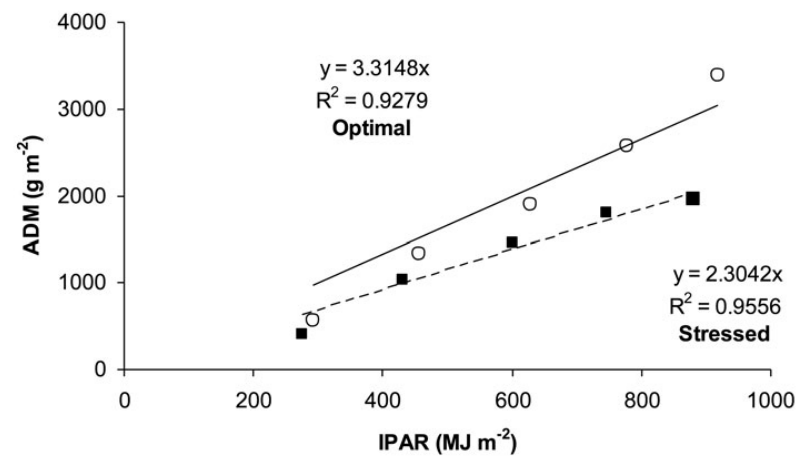

Figure 3. Linear regressions between aboveground dry matter $(A D M)$ and intercepted photosynthetic active solar radiation $(i P A R)$ for the two compared irrigation regimes: optimal = circle, stressed $=$ square, average values of two experimental years. The slopes represent $R U E$. 


\section{Water use efficiency}

Table 4 shows the slopes of the regression line (intercept forced to 0) between irrigation and biomass cumulated by sorghum for each sampling, representing the irrigation water use efficiency (IWUE $\mathrm{kg}$ $\mathrm{m}^{-3}$ ) or biomass produced by plant per cubic meter of irrigation water applied. In sorghum, contrasting results are reported in literature. Tolk and Howell (2003), showed an IWUE decline at increased irrigation, whereas Farrè and Faci (2006), gave the opposite results. Amaducci et al. (2000), report that in a well-watered environment in Northern Italy, fibre sorghum did not take advantage of irrigation, also confirmed by Monti and Venturi (2003), with positive but insignificant effects of irrigation on IWUE. In the first year, a reduction in water supply allowed for an increase of $I W U E$, with higher values in the stressed treatment ( $5.39 \mathrm{~kg} \mathrm{~m}^{-3}$ ) supplying $325 \mathrm{~mm}$ of water, than in the optimal treatment with $4.60 \mathrm{~kg} \mathrm{~m}^{-3}$, providing $505 \mathrm{~mm}$ of water. A reduction in IWUE as a consequence of a decrease in the irrigation regime was also reported for other $\mathrm{C}_{4}$ crops, such as maize, as indicated by Farrè and Faci (2006). This passed from $2.89 \mathrm{~kg} \mathrm{~m}^{-3}$ with $380 \mathrm{~mm}$ of water supplied with irrigation, to $3.57 \mathrm{~kg} \mathrm{~m}^{-3}$ with $100 \mathrm{~mm}$ of irrigation water. On the contrary, in the second year of experiment, no significant statistical differences emerged in $I W U E$ between irrigation treatments, with an average value of $11.44 \mathrm{~kg} \mathrm{~m}^{-3}$, more than double than in 2008. Farrè and Faci (2006), found the same situation in grain sorghum, with no difference in IWUE varying the water regime, even if the value they reported $\left(4.45 \mathrm{~kg} \mathrm{~m}^{-3}\right)$ was very close to the value found in the first year of the experiment.

From these data, it is possible to notice as the IWUE is influenced by other aspects which make this parameter somewhat unreliable in different agricultural conditions. One of these conditions could be the soil water content at sowing; in barley, this is a crucial point for root length and density and consequently for $A D M$, as reported by Sahnoune et al. (2004). They observed that the variation of soil moisture at seedling stage from full to $50 \%$ of field capacity produced a greater root length and, consequently, a larger water used (from $660 \mathrm{~mm}$ to $520 \mathrm{~mm}$ ).

WUE is a crop parameter linked to the productivity, more suitable in different climatic and management conditions and used by different authors to investigate the response of energy biomass crops to the water availability, as reported by Lindroth et al., (1994) and Beale et al. (1999).

In the first year WUE was statistically lower than that obtained in the second year (4.44 $\mathrm{kg} \mathrm{m}^{-3}$ and $7.24 \mathrm{~kg} \mathrm{~m}^{-3}$, respectively; Figure 4). On average, in the two years, no statistical differences in WUE were recorded among the irrigation treatments $\left(5.87 \mathrm{~kg} \mathrm{~m}^{-3}\right)$, but only in the second year the optimal irrigated sorghum proved to be more efficient than the stressed one (Table 4).

This large variability in sorghum $W U E$ as a consequence of different water supplies is confirmed by different authors; Mastrorilli et al. (1995) reported values of WUE in sweet sorghum ranging between 5.6 and $4.1 \mathrm{~kg} \mathrm{~m}^{-3}$ in a Mediterranean environment, despite the small reported differences in water consumption ( 580 and $552 \mathrm{~mm}$ ). A reduction in $W U E$ as a consequence of reduced water is also reported for grain sorghum: in southern Italy, Steduto and Albrizio (2005) found a WUE of $5.7 \mathrm{~kg} \mathrm{~m}^{-3}$ with $510 \mathrm{~mm}$ of water supplied, but this value decreased by $23 \%$ when water use decreased by only $5 \%$. Values of the WUE observed in 2009 are closer to those reported in forage sorghum by Saeed and El-Nadi (1988) in Sudan. They found a variation from 8.6 to $6.9 \mathrm{~kg} \mathrm{~m}^{-3}$, using a fixed amount of water $(700 \mathrm{~mm})$, but varying the time between irrigation events and the relative amount.

In the graph of regression (Figure 4), $A D M v s W U$, the x-axis intercept represents the water lost by soil evaporation (Passioura, 1977). In 2008 , this value was $157 \mathrm{~mm}$, on average, equal to $24 \%$ of seasonal $W U$. In the second year, soil evaporation was double than in 2008 , with an average value of $300 \mathrm{~mm}$, or $40 \%$ of seasonal water use. This so large difference between years can be explained by the different rainfall pat-

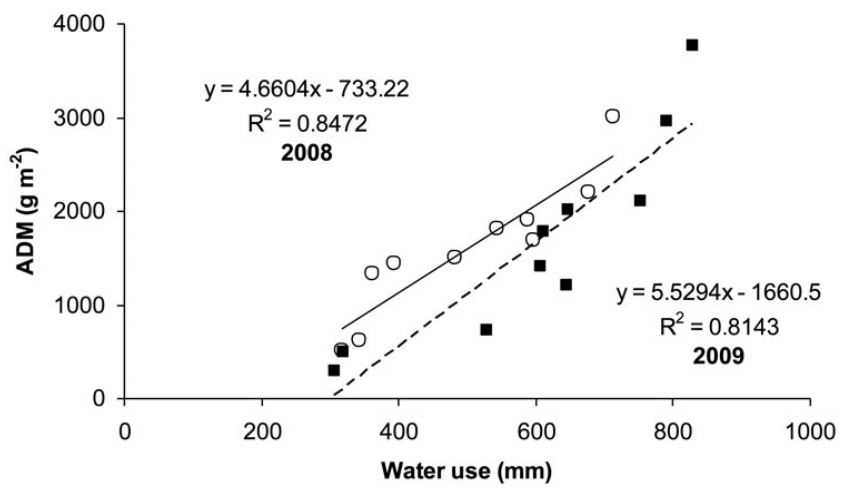

Figure 4. Linear regression between aboveground dry matter $(A D M)$ and water used by biomass sorghum in the two experimental years $(2008=$ circle; $2009=$ square $)$ with average values of the two irrigation regimes. The slopes represent $W U E$.

tern and the available water content in the soil at sowing in 2009. This caused significant evaporation from the top soil, when the canopy did not completely cover the soil surface, and probably, deeper root development in the middle of the growth crop cycle.

\section{Conclusions}

This research was carried out to evaluate the potential of biomass sorghum in the Mediterranean environment as an alternative crop as a renewable energy resource, examining its productivity in terms of biomass produced and its capacity to convert efficiently water and solar radiation. The values of $W U E$ found in this research show that biomass sorghum is a suitable energy crop in a Mediterranean environment, comparable to other energy crops. Moreover, $W U E$ resulted a crop parameter more conservative than IWUE. The RUE values suggested a high yield potential for this crop in well-watered conditions and in a Mediterranean environment. From this study we obtained $R U E$ values for biomass sorghum never previously reported in literature for this specific crop. The observed values were higher than those reported for grain and sweet sorghum, probably due to the prevalence of young and more efficient green leaves in the biomass sorghum, usually harvested before heading. The RUE proved to be significantly dependent on crop water consumption and it cannot be considered a stable crop parameter, at least in the case of biomass sorghum. A reduction of $30 \%$ in RUE was observed with a $35 \%$ decrease in water supply in well-watered conditions. The good results of biomass yield (on average $27.2 \mathrm{t} \mathrm{ha}^{-1}$ of $A D M$ ) indicate that the crop is well suitable to the Mediterranean environment. The main limitation is the amount of water used, on average $700 \mathrm{~mm}$. This requires a large water supply (at least $500 \mathrm{~mm}$ ), which may not always be available and reduce economic convenience. In fact, from this research study it is clear that to fully exploit the potentiality of biomass sorghum in a Mediterranean environment it is necessary to ensure an adequate supply of water during the entire crop growth cycle. Considering the amount of rainfall during the crop cycle (a long-term average of $133 \mathrm{~mm}$ ) and a soil moisture at sowing of approximately $30 \%$ in volume, at least $500 \mathrm{~mm}$ of irrigation water are necessary to obtain a satisfactory amount of biomass from sorghum for energy purposes.

\section{References}

Allen R.G., Pereira L.S., Raes D., Smith M., 1998. Crop evapotranspiration. Guidelines for computing crop water requirements. Irrigation and 
Drainage. FAO Paper No. 56; Roma, Italy.

Albrizio R., Steduto P., 2005. Resource use efficiency of field-grown sunflower, sorghum, wheat and chickpea. I. Radiation use efficiency. Agr. Forest Meteorol. 130:254-268.

Amaducci S., Amaducci M.T., Benati R., Venturi G., 2000. Crop yield and quality parameters of 4 annual fibre crops (Hemp, Kenaf, Maize and Sorghum) in the North of Italy. Ind. Crop. Prod. 11:179-186.

Antonopoulou G., Gavala H.N., Skiadas I.V., Angelopoulos K., Lybearatos G., 2008. Biofuels generation from sweet sorghum: fermentative hydrogen production and anaerobic digestion of the remaining biomass. Bioresour. Technol. 99:110-119.

Beale C.V., Morison J.I.L., Long S.P., 1999. Water use efficiency of C4 perennial grasses in a temperate climate. Agr. Forest Meteorol. 96:103 -115.

Berndes G., Hoogwijk M., Broek R., 2003. The contribution of biomass in the future global energy supply; a review of 17 studies. Biomass Bioenerg. 25:1-28.

Billa E., Koullas D.P., Monties B., Koukious E.G., 1997. Structure and composition of sweet sorghum stalk components. Ind. Crop. Prod. 6:297302.

Charles-Edwards D.A., 1982. Physiological Determinations of Crop Growth. Academic press, Sydney, Australia.

Curt M.D., Fernandez J., Martinez M., 1998. Productivity and Radiation Use Efficiency of sweet sorghum (Sorghum bicolor (L.) Moench) cv. Keller in Central Spain. Biomass Bioenerg. 14:169-178.

Davies W.J., Gowing D.J.G., 1999. Plant response to small perturbations in soil water status. In: J.D. Scholes and M.G. Barker (eds.) Physiological Plant Ecology. Blackwell Science, Oxford, UK, pp 67-89.

Davies W.J., Tardieu F., Trejo C.L., 1994. How do chemical signals work in plants that grown in drying soil? Plant Physiol. 107:309-314.

Dercas N., Liakantas A., 2007. Water and Radiation effect on sweet sorghum productivity. Water Resour. Manag. 21:1585-1600.

FAO-UNESCO, 1963. Bioclimatic map of the Mediterranean Zone, explanatory notes. Paris, France.

Farah S.M., Salih, A.A., Taha, A.M., Ali, Z.I., Ali I.A., 1997. Grain sorghum response to supplementary irrigations under post-rainy season condition. Agr. Water Manage. 33:31-41.

Farrè I., Faci J.M., 2006. Comparative response of maize (Zea mays L.) and sorghum (Sorghum bicolor L. Moench) to deficit irrigation in a Mediterranean environment. Agr. Water Manage. 83:135-143.

Habyarimana E., Laureti D., De Ninno M., Lorenzoni C., 2004. Performances of biomass sorghum [Sorghum bicolor (L.) Moench] under different water regimes in Mediterranean region. Ind. Crop. Prod. 20:23-28.

Hughes G., Keatinge J.D.H., Copper P.J.M, Dee N.F. 1987. Solar radiation interception and utilization by chickpea crops in northern Syria. Journal of Agricultural Science of Cambridge, 108:419-424.

International Energy Agency (IEA), 1998. World Energy Outlook, 1998 edition. Available from: www.iea.org.

Jones J.W., Hoogenboom G., Porter C.H., Boote K.J., Batchelor W.D., Hunt L.A., Wilkens P.W., Singh U., Gijsman A.J., Ritchie J.T., 2003. The DSSAT cropping system model. Eur. J. Agron. 18:235-265.

Krampitz M.J., Klug K., Fock H.P., 1984. Rates of photosynthetic CO2 uptake, photorespiratory $\mathrm{CO} 2$ evolution and dark respiration in waterstressed sunflower and bean leaves. Photosynthetica 18:322-328.

Kreig D.R., Hutmacher R.B., 1986. Photosynthetic rate control in sorghum: stomatal and non-stomatal factors. Crop Sci. 26:112-117.

Lang A.R.G., 1986. Leaf area and average leaf angle from transmittance of direct sunlight. Aust. J. Bot. 34:349-355

Lang A.R.G., 1987. Simplified estimate of leaf area index from transmittance of the sun's beam. Agr. Forest Meteorol. 41:179-186.

Lindroth A., Verwijst T., Halldin S., 1994. Water-use efficiency of willow: variation with season, humidity and biomass allocation. J. Hydrol. 156:1-19.

Ludlow M.M., Ng T.T., 1976. Effects of water deficit on carbon dioxide exchange and leaf elongation rate of Panicum maximum var tri- choglume. Aust. J. Plant Physiol. 3:401-413.

Mastrorilli M., Katerji N., Rana G., Steduto P., 1995. Sweet sorghum in Mediterranean climate: radiation use and biomass water use efficiencies. Ind. Crop. Prod. 3:253-260.

Monteith J.L., 1977. Climate and the efficiency of crop production in Britain. Philos. T. Roy. Soc. B 281:277-294.

Monteith J.L., 1989. Steps in climatology. In: P.W. Unger, W.R. Jordan, T.V., Sneed, R.W., Jensen (Eds.) Proc. Int. Conf. Dryland Farming, Amarillo, Bushland, TX, USA

Monti A., Venturi G., 2003. Comparison of the energy performance of fibre sorghum, sweet sorghum and wheat monocultures in northern Italy. Eur. J. Agron. 19:35-43.

Nilson T., 1971. A theoretical analysis of the frequency of gaps in plant stands. Agr. Meteorol. 8:25-38.

Parikka M., 2004. Global biomass fuel resources. Biomass Bioenerg. 27:613-620.

Passioura J.B., 1977. Grain yield, harvest index, and water use of wheat. J. Aust. Inst. Agric. Sci. 43:117-120.

Perniola M., Tartaglia G., Tarantino E., 1996. Radiation Use Efficiency of sweet sorghum and kenaf under field condition. Proc. 9th. Eur. Bioenergy Conf., Cophenagen, Denmark, page 156 (abstr.).

Ratnavathi C.V., Suresh K., Vijay Kumar B.S., Pallavi M., Komala V.V., Seetharama N., 2010. Study on genotypic variation for ethanol production from sweet sorghum juice. Biomass Bioenerg. 34:947-952.

Saeed I.A.M., El-Nadi A.H., 1988. Forage sorghum yield and water use efficiency under variable irrigation. Irrigation Sci. 18:67-71.

Sahnoune M., Adda A., Soualem S., Harch M., Merah 0., 2004. Early waterdeficit effects on seminal roots morphology in barley. C.R. Biol. 327:389-398.

Sharpley A.N., Williams J.R., 1990. EPIC-Erosion/produc $\neg$ tivity impact calculator: 1) Model documentation. US Department of Agriculture, Technical Bulletin n. 1768. 2) User Manual. U.S. Department of Agriculture, Technical Bulletin n. 1768.

Sinclair T.R., Muchow R.C., 1999. Radiation Use Efficiency. Adv. Agron. 65:215-265

Singh B.R., Singh D.P., 1995. Agronomic and physiological response of sorghum, maize and pearl millet to irrigation. Field Crop Res. 42:5767.

Steduto P., Hsiao T.C., Raes D., Fereres E., 2009. AquaCrop - The FAO Crop Model to Simulate Yield Response to Water: I. Concepts and Underlying Principles. Agron J. 101:426-437.

Steduto P., Albrizio R., 2005. Resource-use efficiency of field grown sunflower, sorghum, wheat and chickpea. II Water use efficiency and comparison with radiation use efficiency. Agr. Forest Meteorol. 130:269281.

Stockle C.0, Donatelli M., Nelson R., 2003. CropSyst, a cropping systems simulation model. Eur. J. Agron. 18:289-307.

Takami S., Rawson H.M., Turner N.C., 1982. Leaf expansion of four sunflower (Helianthus annuus L.) cultivars in relation to water deficits. 2. Patterns during plant development. Plant Cell Environ. 5:279-286.

Tolk J.A., Howell T.A., 2003. Water use efficiencies of grain sorghum grown in three USA Southern Great Plains Soils. Agr. Water Manage. 59:97111.

Troughton J.H., 1969. Plant water stress and carbon dioxide exchange of cotton leaves. Aust. J. Biol. Sci. 22:289-302.

USDA, 2006. Keys to Soil Taxonomy. 10th edn, pp. 333. Available at: ftp:/ftpfc.sc.egov.usda.gov/NSSC/Soil_Taxonomy/keys/keys.pdf.

Varlet-Grancher C., Chartier M., Lemaire G., Grosse G., Bonhomme R., Cruz P., Castal F., Lenoble S., 1992. Productivity of sweet sorghum compared to Sudan-grass and sorghum Sudan grass hybrids: Radiation interception and biomass accumulation under non limiting water and nitrogen condition. In: G. Grassi, A. Collina, and H. Zibetta (eds.) Proc. 6th EC Conf. Biomass for Energy Industry and Environment, Elsevier Applied Science, Oxford, UK, pp 265-267. 